University of Nebraska - Lincoln

DigitalCommons@University of Nebraska - Lincoln

Library Philosophy and Practice (e-journal)

Libraries at University of Nebraska-Lincoln

9-5-2019

Use of Library Resources by the Faculty and Students of Medical and Allied Colleges in Goa State: A Study

Dr. Jayaprakash G. Hugar

Dnyanprassarak Mandal's College and Research Centre, Assagao, Mapusa, Goa, dmclibrarian@rediffmail.com

B U. Kannappanavar Dr.

Sahayadri College, Shivamogga, Karnataka, kannappanavar@gmail.com

Follow this and additional works at: https://digitalcommons.unl.edu/libphilprac

Part of the Library and Information Science Commons

Hugar, Dr. Jayaprakash G. and Kannappanavar, B U. Dr., "Use of Library Resources by the Faculty and Students of Medical and Allied Colleges in Goa State: A Study" (2019). Library Philosophy and Practice (e-journal). 2763.

https://digitalcommons.unl.edu/libphilprac/2763 


\title{
Use of Library Resources by the Faculty and Students of Medical and Allied Colleges in Goa State: A Study
}

\author{
Dr. Jayaprakash G Hugar* \& \\ Dr. Kannappanavar B U**
}

\begin{abstract}
:
Purpose: The purpose of this paper is to determine the data collected from the respondents of the medical and allied colleges in Goa state, with the aim of improving the existing Library an Information Services offered by the medical, dental, nursing, pharmacy, homeopathic and ayurveda colleges in the state.

Methodology: Survey method adopted for the present study. A structured questionnaire was designed keeping the objectives in mind and distributed to the students and faculty members and collected the required primary data. Collected data were analyzed using statistical tools.

Findings: It is clear from the study that, English language is most familiar among the respondents as the percentage of respondents knowing English language is about 99 percent followed by Hindi accounting 95 percent and then Konkani having 81 percent of respondents.Majority of the respondents visit library every day which is followed by the respondents who visit library thrice in a week as their percentage is accordingly around 43 and 20 percent. This indicates that majority of the respondents visit library very frequently. 80 percent of the respondents are having satisfaction about the library working hours. Students feel more convenient than faculties with respect to the location of library.
\end{abstract}

Keywords: Library Resources, Services, Internet, Library use, satisfaction.

* Dr. Jayaprakash G Hugar, Librarian, Dnyanprassarak Mandal's College and Research Centre, Assagao, Bardez, Goa - 403 507. Email: dmclibrarian@ rediffmail.com, ORCID No. http://orcid.org/0000-0001-8307-5582.

** Dr. B.U. Kannappanavar, Sahayadri College, Shimoga, Karnataka, email: kannappanavar@gmail.com

\section{Introduction}


For hundreds of years, printed information sources have been used either by users purchasing them directly from the shops, or by using them through the libraries. The situation began to change about four decades ago with the introduction of computers in information handling, and there has been a dramatic change over the past few years. 'Recent developments in information and communication technologies, especially the Internet and the web, have brought significant changes in the ways we generate, store, access and make use of information in our day to days life(Chowdhury \& Chowdhury, 2003).Being an effective carrier of nascent information, internet plays a significant role in the process of dissemination of information. Internet is now assumed the role of public educator making formal and informal education possible in a large scale, particularly in developed nations where modern communications are easily available.

The Internet thus, finally made the whole world as a global village. The use of Internet in libraries and information centers increased in today's internet era. By providing library services through internet, libraries can increase their efficiency and provide services to users within a fraction of minute. It can be said that Information Communication Technologies will help the libraries to overcome the time and space barriers along with efficient dissemination of the information in a suitable format. Information communication technologies made the libraries to provide its services in a better manner.

Both academic and professional college libraries have started building up their collections both in print and electronic form in order to facilitate the users in using according to their requirements. In recent years the use of electronic information has become prominent in the drive for making information and data transfer available to users, especially students.

\section{Objectives of the Study}

The present study is designed to accomplish the following objectives:

* To identify the purpose of the use of Library Resources among the Faculties and Students of the professional colleges in Goa State.

* To find out the frequency of library visit by the respondents.

* To know the awareness and use of the library resources among the Medical Faculties and Students.

To distinguish the respondents satisfaction of working hours, collection of library materials and access to electronic information sources. 


\section{Methodology}

A suitable questionnaire was designed in keeping view of the objectives of the study, and same was distributed among the Faculties and Students of the Medical and allied Colleges. Survey method was adopted; structured questionnaires are distributed to all the medical, dental, nursing, pharmacy, homeopathic and ayurveda college faculties and students to get full information about the functioning of their college libraries.

\section{Literature Review}

Biradar, B.S. and Maranna, O. (2011) have made a survey indicating the use of electronic resources and services in Marine science research institution libraries by marine scientists in south India. This survey was carried out among marine science research scientists; along with observations at the marine science departments in south India. Information about the availability and use of electronic resources and services, place of access, the purpose of using e-resources, the rank values of use of e-resources in research and teaching, the users visit and time spent on use of e-resources and extent of user's satisfaction with e-resources. Suggestions are also given to strengthen the existing e-resources collection and services. ${ }^{4}$ Singh, R.K. Joteen, Devi, Th. Madhuri and Raychaudhury, Arup (2009) examined the utilization, purpose, difficulties and satisfaction level of users about Internet based e-resource services provided by the library. Identified the low speed internet access, erratic power supply and lack of required full text journals are problems with regard to the use of internet based e-resource. ${ }^{8}$ Atlas, Michel C and others (2007) have made an attempt to study who borrows laptop computers in an academic health sciences library? Why do they choose to check out laptops? In a survey, laptop computer users responded that the laptops were used most frequently to do class-related work. Laptops were most often checked out because they could be taken to a quiet area of the library or to where the user had more room to work. The majority of such borrowers were satisfied or very satisfied with the laptops and the service from the library. The majority of those completing the survey were medical school students and graduate students. The circulation of laptop computers at this academic health sciences library is a very successful and popular program. ${ }^{2}$ Asemi, Asefeh (2005) made a survey on the search habits of Internet users at the Medical University of Isfahan (MUI), a governmental university in Isfahan city, Iran. Efforts are on to find the search requirements related to the use of the Internet information. Using a questionnaire and followup interviews with Internet users from five faculties collected data. Results show that all the 
respondents are using the Internet frequently because all faculties have provided connection to the Internet. It is revealed that the researchers of MUI are getting quality information through the Internet. They use the Internet in different ways, such as accessing to online journals, downloading software or text, chatting, discussion, E-mail services and for finding related references. Also it is observed that the Google and Yahoo search engines are more widely used compared to other search engines. The analysis reveals that 54 percent of Internet users always find useful information on the Internet and finally, 35\% of the studied population use print, online and offline form of information for updating their subject knowledge. ${ }^{1}$

\section{Data Analysis and Interpretation}

Table 5.1 Gender-wise distribution of respondents

\begin{tabular}{|c|c|c|c|}
\hline \multicolumn{1}{|c|}{ Respondents } & Male & Female & Total \\
\hline Faculties & $22(56.4)$ & $17(43.6)$ & $39(100.0)$ \\
\hline Students & $100(23.8)$ & $320(76.2)$ & $420(100.0)$ \\
\hline Total & $122(26.6)$ & $337(73.4)$ & $459(100.0)$ \\
\hline
\end{tabular}

Source: Field survey.

Note: Figures in parenthesis denotes percentage to the total

The above table reveals that among the faculties there is no considerable difference between male and females respondents but with regard to students respondents one fourth of them are male and remaining are females. This difference is justified from the $\mathrm{X}^{2}$ test when it was applied to the data in the above table.

Table 5.2 Language-wise distribution of respondents

\begin{tabular}{|l|c|c|c|}
\hline \multicolumn{1}{|c|}{ Languages Known } & Faculties & Students & Total \\
\hline English & $37(94.9)$ & $416(99.0)$ & $453(98.7)$ \\
\hline Hindi & $37(94.9)$ & $397(94.5)$ & $434(94.6)$ \\
\hline Konkani & $28(71.8)$ & $344(81.9)$ & $372(81.0)$ \\
\hline Marathi & $22(56.4)$ & $251(59.8)$ & $273(59.5)$ \\
\hline Other Languages $^{*}$ & $10(25.6)$ & $78(18.6)$ & $88(19.2)$ \\
\hline
\end{tabular}

Source: Field survey.

Note: Figures in parenthesis denotes percentage to the total $*$ = Portuguese, Sanskrit, French, Kannada and Malayam

Graph 1 Column chart representing percentage of language wise distribution of respondents 


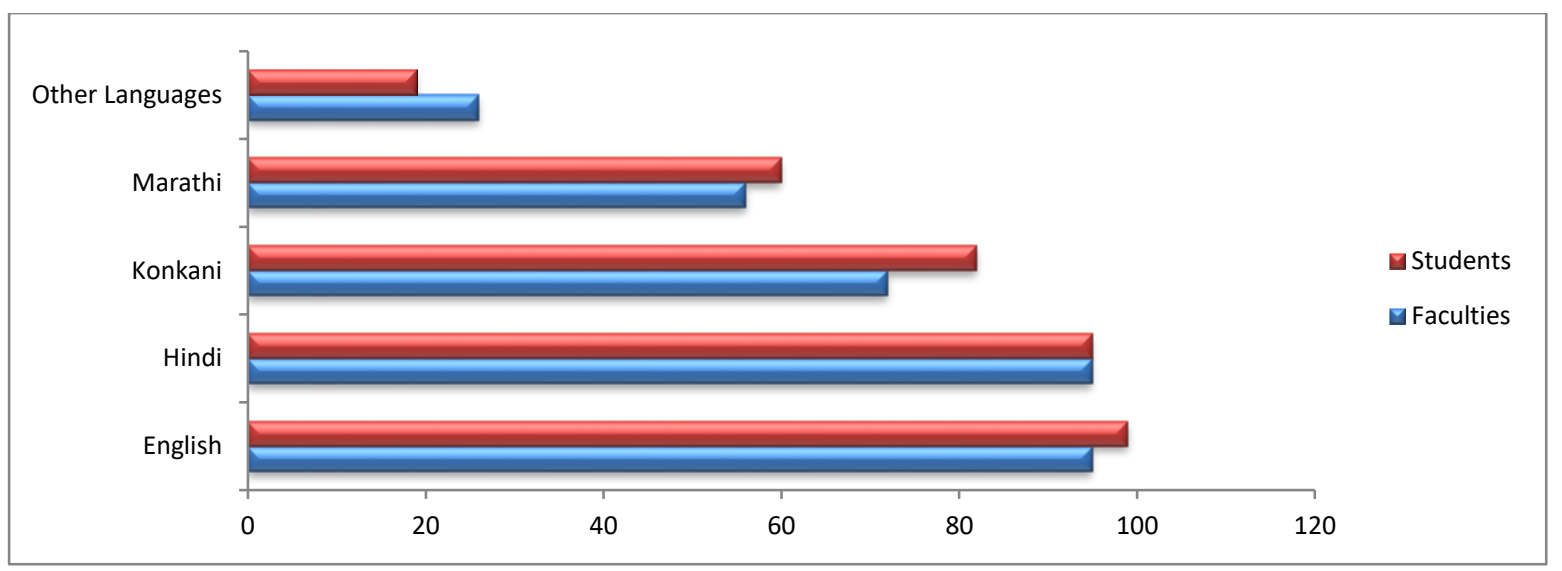

Source: Table 5.3

The data in the above table reveals that Hindi language is most familiar among the respondents as the percentage of respondents knowing English language is about 99 percent where the percentage of faculties is 95 and students is 99 percent followed by Hindi accounting 95 percent with 95 percent of faculties and students each and then Konkani having 81 percent of respondents with 72 percent of faculties and 82 percent of students. However, still about 60 percent of the respondents do familiar with local language Marathi owe 55 percent of faculties and 60 percent of students. At the same time about one fifth of the respondents know other language like Bengali, Kannada, Malayalam, Sanskrit, Portuguese and French. Out of total respondents of faculties, 25 of them are familiar with other language as against to the students whose percentage is very close to it that is 19 percent. All these indicate that respondents are very familiar with English, Hindi and Konkani languages in the study area.

Table 5.3 Respondent's frequency of Library visit

\begin{tabular}{|l|c|c|c|c|c|c|c|}
\hline Respondents & $\begin{array}{c}\text { Every } \\
\text { Day }\end{array}$ & $\begin{array}{c}\text { Once in } \\
\text { a week }\end{array}$ & $\begin{array}{c}\text { Twice } \\
\text { in a } \\
\text { week }\end{array}$ & $\begin{array}{c}\text { Thrice } \\
\text { in a } \\
\text { week }\end{array}$ & Occasionally & $\begin{array}{c}\text { Very } \\
\text { Rarely }\end{array}$ & Total \\
\hline Faculties & $14(35.9)$ & $11(28.2)$ & $1(2.6)$ & $6(15.4)$ & $7(17.9)$ & $0(0.0)$ & $39(100)$ \\
\hline Students & $184(43.8)$ & $72(17.1)$ & $39(9.3)$ & $85(20.2)$ & $31(7.4)$ & $9(2.1)$ & $420(100)$ \\
\hline \multicolumn{1}{|c|}{ Total } & $\mathbf{1 9 8}(\mathbf{4 3 . 1})$ & $\mathbf{8 3}(\mathbf{1 8 . 1})$ & $\mathbf{4 0}(\mathbf{8 . 7})$ & $\mathbf{9 1 ( 1 9 . 8 )}$ & $\mathbf{3 8}(\mathbf{8 . 3})$ & $\mathbf{9 ( 2 . 0 )}$ & $\mathbf{4 5 9}(\mathbf{1 0 0})$ \\
\hline
\end{tabular}

Source: Field survey.

Note: Figures in parenthesis denotes percentage to the total

Among various library visiting timings that is frequency of library visits in the study area it is noticed that, majority of the respondents visit library every day which is followed by the respondents who visit library thrice in a week as their percentage is accordingly around 43 and 20 percent which is followed by the respondents who visit library once in a week accounting for about 18 percent. The percentage of respondents who visit library twice in a 
week, occasionally and very rarely is very low which is below 10 percent. With regard to the respondents visiting library every day, twice in a week, thrice in a week and very rarely the percentage of students is more than faculties and in rest of the frequencies the percentage of faculties is more than students. However, none of the faculties visit library very rarely. This indicates that majority of the respondents visit library very frequently.

Table 5.4 Respondent's satisfaction regarding working hours of library

\begin{tabular}{|c|c|c|c|}
\hline \multicolumn{1}{|c|}{ Respondents } & Satisfied & Not satisfied & Total \\
\hline Faculties & $38(97.4)$ & $1(2.6)$ & $39(100)$ \\
\hline Students & $344(81.9)$ & $76(18.1)$ & $420(100)$ \\
\hline Total & $382(83.2)$ & $77(16.8)$ & $459(100)$ \\
\hline
\end{tabular}

Source: Field survey.

Note: Figures in parenthesis denotes percentage to the total

The satisfaction of library working hours mainly depends upon the working hours of the library. In the study area, it is noticed that the working hours of library is very satisfactory as the percentage of respondents who are satisfied with the working hours of library is about 80 percent out of which faculties are about 97 percent and students about 82 percent. Only about 2.4 and 18.1 percent of the respondents are not satisfied with the existing working hours of the library which indicates that library working hours is convenient to the users.

\section{Graph 2 Bar chart of respondent's satisfaction about library working hours}

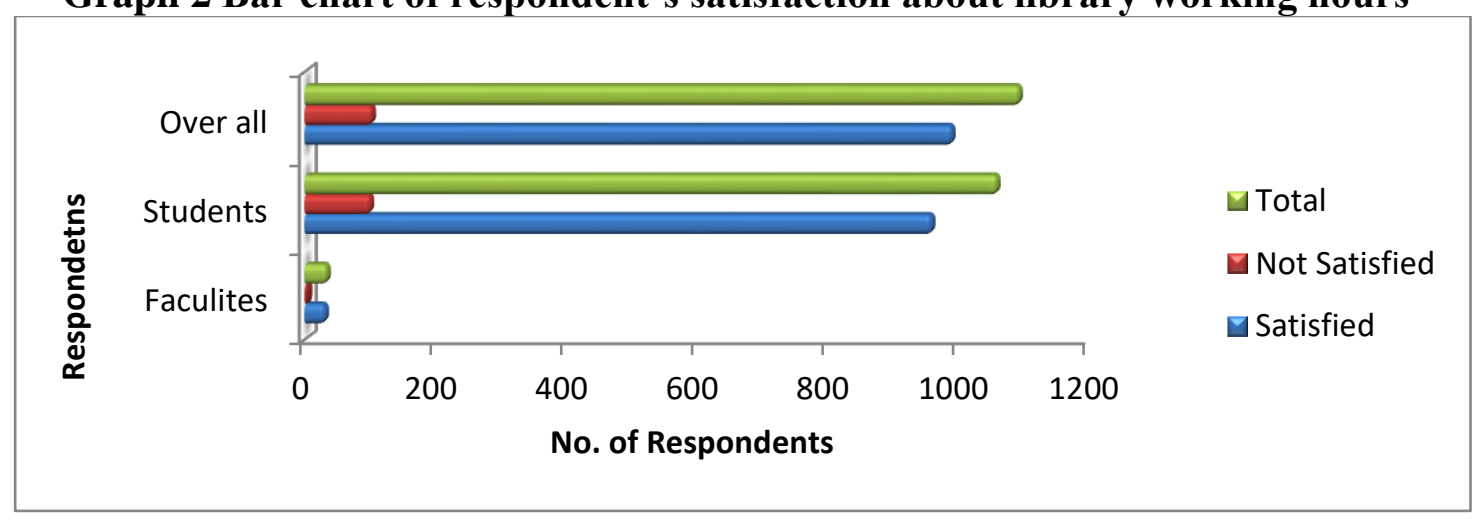

Source: Table 5.5

\section{$\mathrm{X}^{2}$ Analyses:}

$\mathrm{H}_{0}$ : There is insignificant difference regarding satisfaction with the working hours of the library among the respondents.

$\mathrm{H}_{1}$ : There is significant difference regarding satisfaction with the working hours of the library among the respondents.
Level of significance $=0.01$
Degree of freedom $=1$ 
When $\mathrm{X}^{2}$ was applied at 0.01 level of significance with degree of freedom 1 , the calculated value was 6.16 as against the table value of 6.635 which reveals that the difference in satisfaction among the respondents regarding the satisfaction of library working hours is insignificant. That means respondents are satisfied with the existing working hours of the library.

Table 5.5 Respondent's opinion regarding convenience of library location

\begin{tabular}{|c|c|c|c|}
\hline \multicolumn{1}{|c|}{ Respondents } & Yes & No & Total \\
\hline Faculties & $36(92.3)$ & $3(7.7)$ & $39(100.0)$ \\
\hline Students & $393(93.6)$ & $27(6.4)$ & $420(100.0)$ \\
\hline Total & $429(93.5)$ & $30(6.5)$ & $459(100.0)$ \\
\hline
\end{tabular}

Source: Field survey.

Note: Figures in parenthesis denotes percentage to the total

As the use of library depends on its location, the data in the above table indicates that students feel more convenient than faculties with respect to the location of library as their percentage is about 94 while that of faculties is about 92 with the overall percentage of the respondents who are convenient of library location being 94 percent. Though there is some sorts of difference with regard to the convenience of library location, it is of insignificant. This is also evident from $\mathrm{X}^{2}$ test also where the result is as follows:

\section{$\mathrm{X}^{2}$ Analyses:}

$\mathrm{H}_{0}$ : There is no significant difference among the respondents regarding convenience in the location of library.

$\mathrm{H}_{1}$ : There is significant difference among the respondents regarding convenience in the location of library.

Level of significance $=0.01$

Table $\mathrm{X}^{2}$ value $=6.635$
Degree of freedom $=1$

Calculated $\mathrm{X}^{2}$ value $=0.09$

As the calculated $X^{2}$ value (0.09) is less than the table value of $X^{2}$ which is 6.635 , the null hypothesis is accepted and concluded that the difference of opinion among respondents regarding convenience in the location of library is insignificant.

Table 5.6 Respondents time spent in the library 


\begin{tabular}{|l|c|c|c|}
\hline Less than 1 & $23(59.0)$ & $222(52.9)$ & $245(53.4)$ \\
\hline $1-2$ & $14(35.9)$ & $160(38.1)$ & $174(37.9)$ \\
\hline $2-3$ & $1(2.6)$ & $28(6.7)$ & $29(6.3)$ \\
\hline More than 3 & $1(2.6)$ & $10(2.4)$ & $11(2.4)$ \\
\hline Total & 39 & 420 & 459 \\
\hline
\end{tabular}

Source: Field survey.

Note: Figures in parenthesis denotes percentage to the total

With regard to the time spend by the respondents in library, majority of the respondents spend less than an hour or spend in between 1 to 2 hours at library. The percentage of respondents who spend less than an hour in library is around 53 percent which accounts for about 59 percent of faculties and 53 percent of students. Like that those who spend in between 1 to 2 hours the percentage of faculties is about 36 and of students is about 38 percent as against to the overall percentage of 37.9 percent indicating that the percentage of faculties is more than student among those who spend less than an hour in library and the percentage of students is more than faculties those who spend in between 1 to 2 hours in library. The respondents spending in between 2 to 3 hours and more than 3 hours in the library are very low. It is below 7 percent. All this indicates that the time spend by the respondents in the library will be either less than one hour or two.

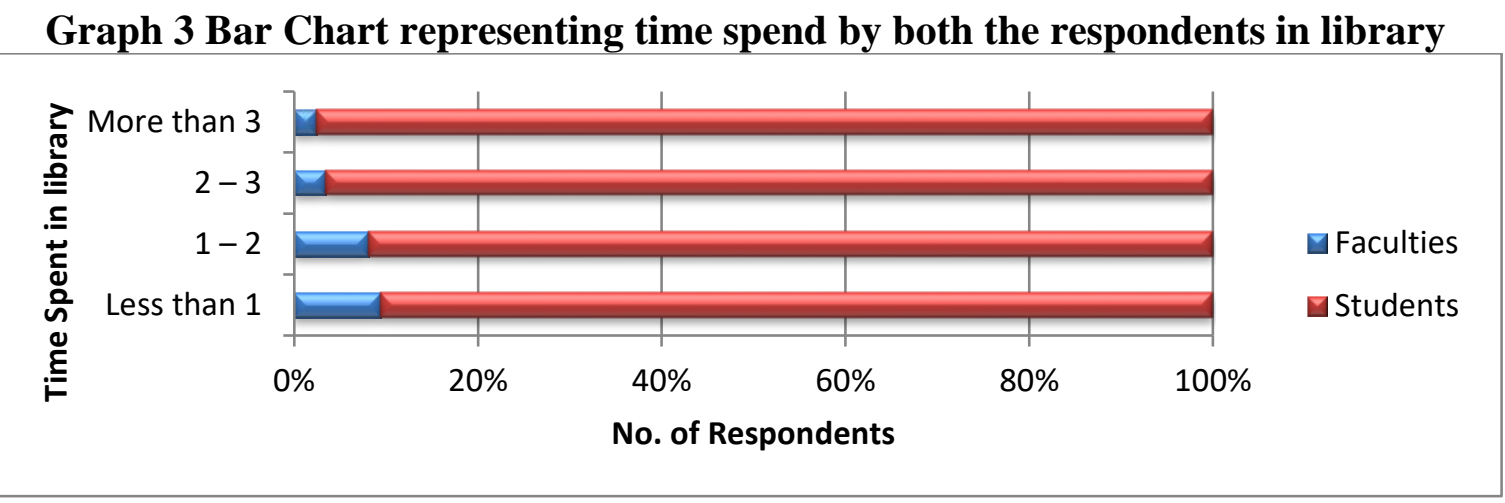

Source: Table 5.7 
Table 5.7 Respondent's purpose of Library visit

\begin{tabular}{|l|c|c|c|c|c|c|}
\hline \multirow{2}{*}{ Purpose of Visit to the Library } & \multicolumn{2}{|c|}{ Faculties } & \multicolumn{2}{c|}{ Students } & \multicolumn{2}{c|}{ Total } \\
\cline { 2 - 7 } & Yes & No & Yes & No & Yes & No \\
\hline \multirow{2}{*}{ Borrow a book } & 23 & 16 & 295 & 125 & 318 & 141 \\
& $(59.0)$ & $(41.0)$ & $(70.2)$ & $(29.8)$ & $(69.3)$ & $(30.7)$ \\
\hline \multirow{2}{*}{ Refer the books / journal } & 28 & 11 & 283 & 137 & 311 & 148 \\
& $(71.8)$ & $(28.2)$ & $(67.4)$ & $(32.6)$ & $(67.8)$ & $(32.2)$ \\
\hline \multirow{2}{*}{ Read magazines } & 12 & 27 & 81 & 339 & 93 & 366 \\
& $(30.8)$ & $(69.2)$ & $(19.3)$ & $(80.7)$ & $(20.3)$ & $(79.7)$ \\
\hline \multirow{2}{*}{ Prepare assignment and notes } & 10 & 29 & 227 & 193 & 237 & 222 \\
& $(25.6)$ & $(74.4)$ & $(54.0)$ & $(46.0)$ & $(51.6)$ & $(48.4)$ \\
\hline Search the source book of general & 9 & 30 & 29 & 391 & 38 & 421 \\
knowledge & $(23.1)$ & $(76.9)$ & $(6.9)$ & $(93.1)$ & $(8.3)$ & $(91.7)$ \\
\hline \multirow{2}{*}{ Search database and CD's } & 1 & 38 & 11 & 409 & 12 & 447 \\
\hline \multirow{2}{*}{ Use Internet and search online source } & $(2.6)$ & $(97.4)$ & $(2.6)$ & $(97.4)$ & $(2.6)$ & $(97.4)$ \\
\hline Recreation and meeting friends & $(5.1)$ & $(94.9)$ & $(9.3)$ & $(90.7)$ & $(8.9)$ & $(91.1)$ \\
\hline
\end{tabular}

Source: Field survey.

Note: Figures in parenthesis denotes percentage to the total

With respect to various purposes of library visits, in the study area it is studied that, major purpose of visit to library will be to borrow book which is around 69 percent followed by referring the book or journals and prepare assignments or notes accounting for about 68 and 52 percent respectively. Students visit library more than faculties to borrowing book and preparing assignments as their percentage which is about 70 and 54 is more than faculties which is 59 and 26 percent. But faculties visit library more for referring books or journals than students whose percentage is about 72 and 67 respectively. One fifth of the respondents visit to library is for reading magazines where again the percentage of faculty's is more than the percentage of student's. With respect to the remaining purposes of visit to library like for searching source book of general knowledge, search database and CDs, use internet and search online resources and for recreation and meeting is very low which is below 10 percent. Therefore, it can be concluded that the main purpose of visiting library will be either borrow book or to refer book/ journal or to prepare assignments / notes.

\section{ANOVA Analysis:}

$\mathrm{H}_{0}$ : There is insignificant difference among the respondents regarding purpose of visiting library.

$\mathrm{H}_{1}$ : There is significant difference among the respondents regarding purpose of visiting library. 


\begin{tabular}{|c|c|c|c|c|c|c|}
\hline \multicolumn{7}{|c|}{ ANOVA Table } \\
\hline Source of Variation & $S S$ & $d f$ & $M S$ & $F$ & P-value & F crit \\
\hline Between Groups & 52900 & 1 & 52900 & 7.16277023 & 0.0180746 & 4.60011 \\
\hline Within Groups & 103395.75 & 14 & 7385.4 & & & \\
\hline Total & 156295.75 & 15 & & & & \\
\hline
\end{tabular}

At 0.05 level of significance and for degree of freedom of 1 and 14 the table value of $F=4.60011$. Like that the Calculated value of $F=7.16277023$. As the calculated value of $F$ is more than the table $\mathrm{F}$ value, it can be stated that there is significant difference among the respondents with regard to the purpose of visit to library.

Table 5.8 Respondent's awareness about Reference Sources

\begin{tabular}{|l|c|c|c|c|c|c|}
\hline \multirow{2}{*}{ Reference Sources } & \multicolumn{2}{c|}{ Faculties } & \multicolumn{2}{c|}{ Students } & \multicolumn{2}{c|}{ Total } \\
\cline { 2 - 7 } & Yes & No & Yes & No & Yes & No \\
\hline \multirow{2}{*}{ Dictionaries } & 30 & 9 & 311 & 109 & 341 & 118 \\
& $(76.9)$ & $(23.1)$ & $(74.0)$ & $(26.0)$ & $(74.3)$ & $(25.7)$ \\
\hline \multirow{2}{*}{ Encyclopedias } & 22 & 17 & 247 & 173 & 269 & 190 \\
& $(56.4)$ & $(43.6)$ & $(58.8)$ & $(41.2)$ & $(58.6)$ & $(41.4)$ \\
\hline \multirow{2}{*}{ Directories } & 6 & 33 & 87 & 333 & 93 & 366 \\
& $(15.4)$ & $(84.6)$ & $(20.7)$ & $(79.3)$ & $(20.3)$ & $(79.7)$ \\
\hline \multirow{2}{*}{ Year Books } & 19 & 20 & 194 & 226 & 213 & 246 \\
& $(48.7)$ & $(51.3)$ & $(46.2)$ & $(53.8)$ & $(46.4)$ & $(53.6)$ \\
\hline \multirow{2}{*}{ Hand Books } & 18 & 21 & 219 & 201 & 237 & 222 \\
& $(46.2)$ & $(53.8)$ & $(52.1)$ & $(47.9)$ & $(51.6)$ & $(48.4)$ \\
\hline \multirow{2}{*}{ Geographical Information Sources } & 3 & 36 & 52 & 368 & 55 & 404 \\
& $(7.7)$ & $(92.3)$ & $(12.4)$ & $(87.6)$ & $(12.0)$ & $(88.0)$ \\
\hline Biographical Information Sources & 8 & 31 & 101 & 319 & 109 & 350 \\
& $(20.5)$ & $(79.5)$ & $(24.0)$ & $(76.0)$ & $(23.7)$ & $(76.3)$ \\
\hline Electronic Reference Sources & 7 & 32 & 83 & 337 & 90 & 369 \\
& $(17.9)$ & $(82.1)$ & $(19.8)$ & $(80.2)$ & $(19.6)$ & $(80.4)$ \\
\hline Books of Facts/Current Information & 15 & 24 & 205 & 215 & 220 & 239 \\
Sources & $(38.5)$ & $(61.5)$ & $(48.8)$ & $(51.2)$ & $(47.9)$ & $(52.1)$ \\
\hline
\end{tabular}

Source: Field survey. Note: Figures in parenthesis denotes percentage to the total

With respect to the awareness about reference sources among the respondents, from the survey in the study area, it is noticed that, about three forth of the respondents are aware about dictionaries followed by encyclopedias, handbooks and directories all which are above 50 percent. Like that with regard to the awareness among the respondents about geographical information sources, biographical information sources and electronic reference sources, the percentage of respondents is below one fourth that is below 25 percent. Except dictionaries and yearbooks the awareness of students in rest all reference source is more than faculties. 
The data in the above table indicates that among the respondents the awareness about dictionaries is more with respect to various reference sources available in the library.

\section{ANOVA Analysis:}

$\mathrm{H}_{0}$ : There is insignificant difference among the respondents regarding reference sources.

$\mathrm{H}_{1}$ : There is significant difference among the respondents regarding reference sources.

\begin{tabular}{|c|c|c|c|c|c|c|}
\hline \multicolumn{7}{|c|}{ ANOVA Table } \\
\hline Source of Variation & $S S$ & $d f$ & $M S$ & $F$ & P-value & F crit \\
\hline Between Groups & 104424.5 & 1 & 104424.5 & 26.2374 & 0.000102 & 4.493998 \\
\hline Within Groups & 63679.78 & 16 & 3979.986 & & & \\
\hline Total & 168104.3 & 17 & & & & \\
\hline
\end{tabular}

As the calculated $F$ value is less than the table $F$ value, null hypothesis can be accepted and concluded that there is insignificant difference regarding the perception of the respondents with respect to the reference sources available at their respective libraries.

Table 5.9 Respondents usage regarding sources of information in the library

\begin{tabular}{|l|c|c|c|}
\hline \multicolumn{1}{|c|}{ Information Sources } & Faculties & Students & Total \\
\hline Books & $35(89.7)$ & $387(92.1)$ & $422(91.9)$ \\
\hline Printed Journals & $19(48.7)$ & $129(30.7)$ & $148(32.2)$ \\
\hline Electronic Journals & $5(12.8)$ & $56(13.3)$ & $61(13.3)$ \\
\hline General Web Sources & $12(30.8)$ & $142(33.8)$ & $154(33.6)$ \\
\hline
\end{tabular}

Source: Field survey.

Note: Figures in parenthesis denotes percentage to the total

Mere collection of resources will not serve the purpose of the library users. The users who visit library should make use of the collection that exits in the library. From that point of view, from the survey it is found that the main purpose of all respondents to visit library is to use books. Very low percent of respondents say about one third of them visit library for the purpose of referring web sources followed by printed journals. This accounted for about 34 and 32 percent among total respondents where the percentage of faculties is more with respect to general web sources and the percent of students is more among those who referred printed journals. Though about 34 percent of the respondents referred general web sources in the library but their percentage in using electronic journals or referring electronic journals is very low which accounts for only about 13 percent and surprisingly the students refer more electronic journals than faculties do which indicates students are more familiar with electronic resources. On the other hand there is a very low percentage of reference of general 
magazines, senior notes, etc., in the library from the respondents. Here it is interesting to note that none of the faculties refer senior notes or general magazines where students do for about 4 percent.

\section{$\mathrm{X}^{2}$ Analyses:}

$\mathrm{H}_{0}$ : There is no significant difference regarding sources of information in the library among the respondents.

$\mathrm{H}_{1}$ : There is significant difference regarding sources of information in the library among the respondents.

Level of significance $=0.01$

Table $X^{2}$ value $=6.635$
Degree of freedom $=1$

Calculated $\mathrm{X}^{2}$ value $=0.0516232$

The calculated $X^{2}$ value $=0.0516232$ and the table $X^{2}$ value $=6.635$. As the calculated $X^{2}$ value is less than the table $X^{2}$ value, null hypothesis is accepted and concluded that there is insignificant difference among the respondents regarding the perception with respect to the sources of information at their respective library.

Table 5.10 Respondent's satisfaction regarding collections in the library

\begin{tabular}{|l|c|c|c|c|c|c|}
\hline \multirow{2}{*}{ Collections } & \multicolumn{2}{|c|}{ Faculties } & \multicolumn{2}{c|}{ Students } & \multicolumn{2}{c|}{ Total } \\
\cline { 2 - 7 } & Yes & No & Yes & No & Yes & No \\
\hline \multirow{2}{*}{ Text Books } & 28 & 11 & 342 & 78 & 370 & 89 \\
& $(71.8)$ & $(28.2)$ & $(81.4)$ & $(18.6)$ & $(80.6)$ & $(19.4)$ \\
\hline \multirow{2}{*}{ Reference Books } & 20 & 19 & 259 & 161 & 279 & 180 \\
& $(51.3)$ & $(48.7)$ & $(61.7)$ & $(38.3)$ & $(60.8)$ & $(39.2)$ \\
\hline \multirow{2}{*}{ Periodicals/journals } & 28 & 11 & 247 & 173 & 275 & 184 \\
& $(71.8)$ & $(28.2)$ & $(58.8)$ & $(41.2)$ & $(59.9)$ & $(40.1)$ \\
\hline \multirow{2}{*}{ Question Papers } & 28 & 11 & 332 & 88 & 360 & 99 \\
& $(71.8)$ & $(28.2)$ & $(79.0)$ & $(21.0)$ & $(78.4)$ & $(21.6)$ \\
\hline \multirow{2}{*}{ Newspapers } & 30 & 9 & 322 & 98 & 352 & 107 \\
& $(76.9)$ & $(23.1)$ & $(76.7)$ & $(23.3)$ & $(76.7)$ & $(23.3)$ \\
\hline \multirow{2}{*}{ Magazines } & 21 & 18 & 236 & 184 & 257 & 202 \\
& $(53.8)$ & $(46.2)$ & $(56.2)$ & $(43.8)$ & $(56.0)$ & $(44.0)$ \\
\hline \multirow{2}{*}{ Electronic Resources } & 9 & 30 & 71 & 349 & 80 & 379 \\
& $(23.1)$ & $(76.9)$ & $(16.9)$ & $(83.1)$ & $(17.4)$ & $(82.6)$ \\
\hline \multirow{2}{*}{ Scientific/ Technical Reports } & 10 & 29 & 102 & 318 & 112 & 347 \\
& $(25.6)$ & $(74.4)$ & $(24.3)$ & $(75.7)$ & $(24.4)$ & $(75.6)$ \\
\hline \multirow{2}{*}{ Patents } & 8 & 31 & 96 & 324 & 104 & 355 \\
& $(20.5)$ & $(79.5)$ & $(22.9)$ & $(77.1)$ & $(22.7)$ & $(77.3)$ \\
\hline \multirow{2}{*}{ Standards } & 7 & 32 & 98 & 322 & 105 & 354 \\
& $(17.9)$ & $(82.1)$ & $(23.3)$ & $(76.7)$ & $(22.9)$ & $(77.1)$ \\
\hline
\end{tabular}


The success of any library depends upon the collection of resources in it. In the study area more than three fourth of the respondents are satisfied or happy with the collection of text books, question papers and newspapers which is followed by the collection of periodicals/ journals, reference books and magazines which accounts for about 60 percent of the respondents except for magazine which is only about 50 percent. With respect to the collection of electronic resources, technical reports, patents and standards the respondents are very little satisfied or happy as their percentage with this respect is below one fourth of the total that is less than 25 percent. At the same time respondents are not at all satisfied with the collection of other relevant materials other than the above mentioned ones. This is because the level of happiness is only 3 percent. On the other hand regarding the collection of periodicals/ journals, newspapers, electronic resources, scientific or technical reports and other materials the percentage of faculties who are satisfied are more than students and in the remaining collections the percentage of students is more than faculties. Totally it can be concluded that respondents are only satisfied with the collection of text books, reference books, periodicals or journals, question papers and newspapers. This indicates that there is urgent need to concentrate on the collection of electronic resources, technical reports, patents and standard reports which are more essential and needs in present situation for students, faculties and research scholars.

\section{ANOVA Analysis:}

$\mathrm{H}_{0}$ : There is insignificant difference among the respondents regarding satisfaction with respect to the collections at their libraries.

$\mathrm{H}_{1}$ : There is significant difference among the respondents regarding satisfaction with respect to the collections at their libraries.

\begin{tabular}{|c|c|c|c|c|c|c|}
\hline \multicolumn{7}{|c|}{ ANOVA Table } \\
\hline Source of Variation & $S S$ & $d f$ & $M S$ & $F$ & P-value & F crit \\
\hline Between Groups & 183552.8 & 1 & 183552.8 & 30.98362 & $2.77 \mathrm{E}-05$ & 4.413873 \\
\hline Within Groups & 106635.4 & 18 & 5924.189 & & & \\
\hline Total & 290188.2 & 19 & & & & \\
\hline
\end{tabular}

As the calculated $\mathrm{F}$ value which is 30.98362 which is more than the table $\mathrm{F}$ value which is 4.413873 , null hypothesis is rejected and alternative hypothesis is accepted. Therefore, it can be concluded that there exist significant difference with regard to the satisfaction of the respondents with respect to the collections at their library. 
Table 5.11 - A: Respondents satisfaction regarding access of Electronic information sources in the library

\begin{tabular}{|l|c|c|c|c|c|c|}
\hline \multirow{2}{*}{ Collections } & \multicolumn{2}{|c|}{ Faculties } & \multicolumn{2}{c|}{ Students } & \multicolumn{2}{c|}{ Total } \\
\cline { 2 - 7 } & Yes & No & Yes & No & Yes & No \\
\hline Audio/Video Cassettes & $5(12.8)$ & $\begin{array}{c}34 \\
(87.2)\end{array}$ & $31(7.4)$ & $\begin{array}{c}389 \\
(92.6)\end{array}$ & $36(7.8)$ & $\begin{array}{c}423 \\
(92.2)\end{array}$ \\
\hline CD/DVDs & $3(7.7)$ & $\begin{array}{c}36 \\
(92.3)\end{array}$ & $34(8.1)$ & $\begin{array}{c}386 \\
(91.9)\end{array}$ & $37(8.1)$ & $\begin{array}{c}422 \\
(91.9)\end{array}$ \\
\hline $\begin{array}{l}\text { Internet \& Online } \\
\text { Resources }\end{array}$ & 15 & $\begin{array}{c}24 \\
(61.5)\end{array}$ & $\begin{array}{c}127 \\
(30.2)\end{array}$ & $\begin{array}{c}293 \\
(69.8)\end{array}$ & $\begin{array}{c}142 \\
(30.9)\end{array}$ & $\begin{array}{c}317 \\
(69.1)\end{array}$ \\
\hline
\end{tabular}

Source: Field survey.

Note: Figures in parenthesis denotes percentage to the total

It is studied that audio and video like cassettes, Compact Discs (CDs), digital versatile disks (DVDs) and internet are the some of the strongest electronic Medias which anybody normally come across. In the study area it is surveyed that majority of the respondents are not happy with the use of electronic sources available in their library. Among the available audio and video sources accessed by the respondents in the library, internet and online resources is accessed in more by the respondents that too only about 31 percent where the percentage of faculties is about 39 and that of students is about 30 percent indicating that faculties are more happy in accessing audio and video resources than students in their library. The percentage of respondents who are happy with the access of the audio or video cassettes and CD/ DVDs is very little accounting for only about 8 percent. Here the percentage of faculties is more than students with respect to the happiness in accessing audio/ video cassettes and the percentage of students is more with respect to the happiness in accessing CD/ DVDs in their library. All this indicates that still there is a long way to go in increasing the happiness of the respondents in accessing audio/ video information sources in their library.

\section{ANOVA Analyses:}

$\mathrm{H}_{0}$ : There is no significant difference regarding access of electronic information sources at their library.

$\mathrm{H}_{1}$ : There is significant difference regarding access of electronic information sources at their library.

\begin{tabular}{|c|c|c|c|c|c|c|}
\hline \multicolumn{7}{|c|}{ ANOVA Table } \\
\hline Source of Variation & $S S$ & $d f$ & $M S$ & $F$ & P-value & F crit \\
\hline Between Groups & 4760.167 & 1 & 4760.167 & 3.15208 & 0.150487 & 7.708647 \\
\hline Within Groups & 6040.667 & 4 & 1510.167 & & & \\
\hline Total & 10800.83 & 5 & & & & \\
\hline
\end{tabular}


As the calculated $\mathrm{F}$ value is less than the table $\mathrm{F}$ value, null hypothesis is accepted and concluded that there exist insignificant difference with regard to the satisfaction of the respondents with respect to the access of information sources at their library.

Table 5.11 - B: Respondents dependency on library sources

\begin{tabular}{|l|c|c|c|c|c|}
\hline \multirow{2}{*}{ Respondents } & \multicolumn{4}{|c|}{ Dependency } & \multirow{2}{*}{ Total } \\
\cline { 2 - 5 } & Below 25 & $\mathbf{2 5}-\mathbf{5 0}$ & $\mathbf{5 0}-\mathbf{7 5}$ & Above 75 & \\
\hline Faculties & $17(43.6)$ & $13(33.3)$ & $7(17.9)$ & $2(5.1)$ & $\mathbf{3 9}$ \\
\hline Students & $93(22.1)$ & $169(40.2)$ & $118(28.1)$ & $40(9.5)$ & $\mathbf{4 2 0}$ \\
\hline \multicolumn{1}{|c|}{ Total } & $\mathbf{1 1 0}(\mathbf{2 4 . 0})$ & $\mathbf{1 8 2 ( 3 9 . 6 )}$ & $\mathbf{1 2 5}(\mathbf{2 7 . 2})$ & $\mathbf{4 2}(\mathbf{9 . 2})$ & $\mathbf{4 5 9}$ \\
\hline
\end{tabular}

Source: Field survey.

Note: Figures in parenthesis denotes percentage to the total

It is studied that greater percentage of dependence is there on library sources which gives way to analyse to what extent the dependence of respondents is there on library sources. The above table clearly reveals the percentage of dependence of the respondents on the library sources. From the data in the above table it is clear that the dependence of respondents on library sources is less than 50 percent. In other words, about 64 percent of the respondents depend on library sources either less than 25 percent or in between 25 to 50 percent whose percentage is accordingly 24 and 40 percent. Very less respondents say about 27 percent depend on library sources for more than 50 percent but less than 75 percent and still less percent of the respondent that is only about 9 percent depend on library sources. All these indicate that the maximum dependence of respondents on library sources is within 50 percent and in certain cases up to 75 percent.

\section{Graph 4 Column chart regarding respondent's dependency on library}

Faculties

Students

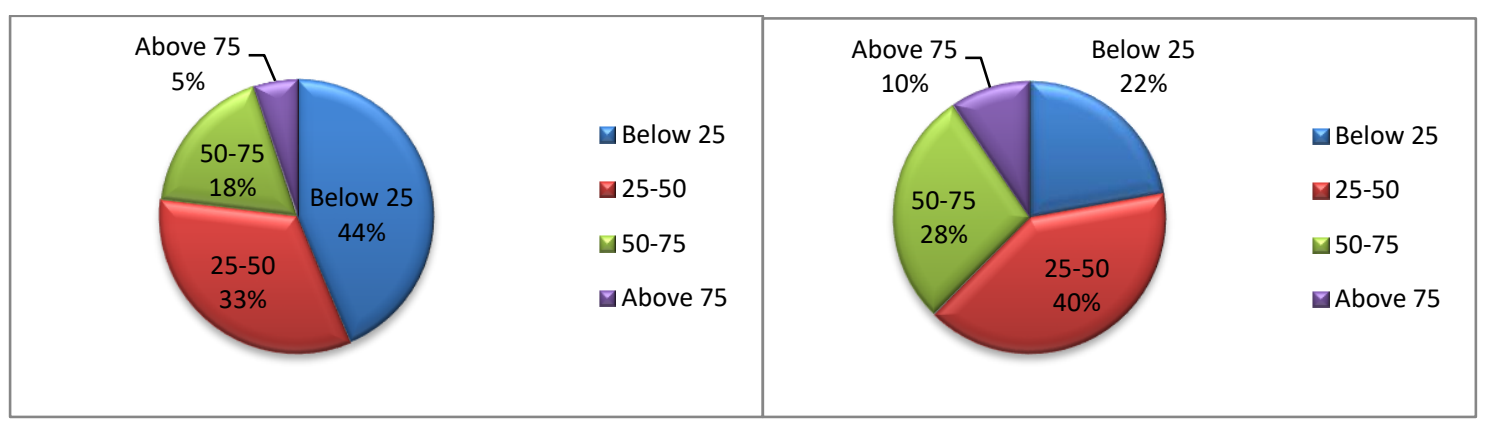

Source: Table $5.12-\mathrm{B}$ 
Table 5.12 Respondents preference regarding media of information resources in library

\begin{tabular}{|l|c|c|c|c|}
\hline Respondents & Print Media & Electronic Media & Both & Total \\
\hline Faculties & $13(33.3)$ & $17(43.6)$ & $9(23.1)$ & $39(100.0)$ \\
\hline Students & $160(38.1)$ & $149(35.5)$ & $111(26.4)$ & $420(100.0)$ \\
\hline \multicolumn{1}{|c|}{ Total } & $173(37.7)$ & $166(36.2)$ & $120(26.1)$ & $459(100.0)$ \\
\hline
\end{tabular}

Source: Field survey.

Note: Figures in parenthesis denotes percentage to the total

User can use print media or electronic media to access the required information. To access print media hard copy of the information is required and to access electronic media electronic devices are required. In the study area, there is a mixed preference with regard to the use of media of information resources in the library. The overall percent of the respondents using print media is about 38 percent, electronic media is about 36 percent and respondents using both are about 26 percent. Among them with respect to print media around 38 and 33 percent of them are students and faculties, in electronic media around 44 and 36 percent are faculties and students and among the respondents using both around 23 and 26 are faculties and students. This reveals that the respondents equally prefer both print media and electronic media.

\section{$\mathrm{X}^{2}$ Analyses:}

$\mathrm{H}_{0}$ : There is insignificant difference regarding preference with respect to media information resources.

$\mathrm{H}_{1}$ : There is significant difference regarding preference with respect to media information resources.

$$
\begin{array}{ll}
\text { Level of significance }=0.01 & \text { Degree of freedom }=2 \\
\text { Table } X^{2} \text { value }=5.991 & \text { Calculated } X^{2}=11.42
\end{array}
$$

As the calculated $\mathrm{X}^{2}$ value is less than the table $\mathrm{X}^{2}$ value, null hypothesis accepted and it can be concluded that there is insignificant difference among the respondents regarding the preference with respect to media information resources.

\section{Key Findings}

6.1 It is clear from the study that, English language is most familiar among the respondents as the percentage of respondents knowing English language is about 99 percent followed by Hindi accounting 95 percent and then Konkani having 81 percent of respondents. 
6.2 Majority of the respondents visit library every day which is followed by the respondents who visit library thrice in a week as their percentage is accordingly around 43 and 20 percent. This indicates that majority of the respondents visit library very frequently.

6.380 percent of the respondents are having satisfaction about the library working hours. Students feel more convenient than faculties with respect to the location of library

6.4 Majority of the respondents spend less than an hour or spend in between 1 to 2 hours at library.

6.5 Major purpose of visit to library will be to borrow book which is around 69 percent followed by referring the book or journals and prepare assignments or notes accounting for about 68 and 52 percent respectively.

6.6 It is noticed that, about three forth of the respondents are aware about dictionaries followed by encyclopedias, handbooks and directories all which are above 50 percent.

6.7 In the study area more than three fourth of the respondents are satisfied or happy with the collection of text books, question papers and newspapers which is followed by the collection of periodicals/ journals, reference books and magazines.

6.8 It is found that the main purpose of all respondents to visit library is to use books. Very low percent of respondents say about one third of them visit library for the purpose of referring web sources followed by printed journals.

6.9 Majority of the respondents are not happy with the use of electronic sources available in their library.

6.10 All these indicate that the maximum dependence of respondents on library sources is within 50 percent and in certain cases up to 75 percent.

6.11 The overall percent of the respondents using print media is about 38 percent, electronic media is about 36 percent and respondents using both are about 26 percent. This reveals that the respondents equally prefer both print media and electronic media. 


\section{Suggestions}

7.1 To make users to use the library for more than hour, library staff should be very proactively work towards the benefit of the students and staff members. Faculties should give more assignments and project work to the students then, students will use and spend maximum time in the library.

7.2 To make maximum utilization of e-resources, librarian has to undertake information literacy programme or conduct rigorously orientation programme to all the students and staff in updating the existing library facilities and their uses.

7.3 Internet bandwidth and speed should be increased.

7.4 Libraries should get latest edition of books and other resources for the benefit of the library users.

\section{Conclusion}

Information is very important in this internet era and this information is available in different formats Libraries main aim is to disseminate the required information to its users at right time in a meaningful way. Medical and allied college libraries should procure latest resources in both print as well as electronic format, so users can maximize their usefulness of the library resources. The library services supplemented by Internet services can prove a great boon to the users in getting the right information at the right time. Concludes that it is essential for libraries and their staff to adapt to the changing circumstances and points out the necessity of effective communication between users and the libraries. 


\section{References:}

1. Asemi, A. (2005). Information Searching Habits of Internet Users: A Case Study on the Medical Sciences University of Isfahan, Iran. Webology, 2 (1).

2. Atlas, M. C., Garza, F., \& Ren, H. (2007). Use of Laptop Computers in an Academic Medical Library. Medical Reference Services Quarterly, 26 (2), 27-36.

3. Baruchson-Arbib, S., \& Shor, F. (2002). Use of Electronic Information Sources by Israeli College Students. Journal of Academic Librarianship, 28 (4), 255-257.

4. Biradar, B. S., \& Maranna. O. (2011). Use of Electronic Resources and Services by Marine Scientists in South India. Journal of Indian Library Association, 48 (1), 12-23.

5. Black, R., Harrison, J. M., Morris, D., Sara, B., Tod, Angela., \& Wolstenholme, D. (2004). Nurses Use of the Internet in Clinical Ward Settings. Journal of Advanced Nursing, 48 (2), 157-166.

6. Chowdhury, G. G., \& Chowdhury , S. C. (2003). Introduction to Digital Libraries . London: Facet Publishing.

7. Kumbar, M., \& Shirur, S. (2003). Internet and Its Use in Sree Jayachamarajendra College of Engineering: A Case Study. SRELS Journal of Information Management, 40 (2), 169176.

8. Singh, R. K. Joteen., Devi Th. Madhuri., \&Raychaudhury, Arup. (2009). Use of Internet based e-resources at Manipur University: a survey. Annals of Library and Information Studies, 56(1), 52-57. 